\title{
KAJIAN DISTRIBUSI SPASIAL SALINITAS AIRTANAH BERDASARKAN KANDUNGAN KLORIDA DI PULAU PRAMUKA, KEPULAUAN SERIBU, DKI JAKARTA
}

\author{
Ahmad Cahyadi, Muh Aris Marfai, Tommy Andryan Tivianton, Wulandari \\ dan Wahyu Hidayat \\ Jurusan Geografi Lingkungan Fakultas Geografi Universitas Gadjah Mada \\ Email: ahmadcahyadi@geo.ugm.ac.id
}

\section{INTISARI}

Pulau Pramuka sebagai pulau sangat kecil (luas kurang dari $100 \mathrm{~km}^{2}$ ) memiliki karakteristik hidrologi yang unik. Airtanah pada pulau tersebut berbentuk lensa airtanah yang rawan mengalami pencemaran dan intrusi air laut. Wilayah yang sempit menyebabkan imbuhan airtanah sangat sedikit, sedangkan di sisi lain pertumbuhan penduduk dengan segala aktivitasnya menyebabkan kebutuhan air menjadi semakin banyak. Kondisi demikian menyebabkan kerawanan terjadinya intrusi air laut di Pulau Pramuka menjadi semakin tinggi. Penelitian ini bertujuan untuk mengetahui sebaran spasial salinitas airtanah di Pulau Pramuka berdasarkan sebaran spasial nilai klorida. Penelitian dilakukan dengan menganalisis kandungan klorida dalam airtanah yang diambil dari sumur. Hasil pengukuran kemudian dianalisis dengan analisis geostatistik untuk menentukan interpolasi yang paling sesuai. Hasil penelitian menunjukkan bahwa airtanah di Pulau Pramuka didominasi oleh air payau dan asin. Hal ini menunjukkan bahwa intrusi air laut telah menyusup ke lensa airtanah. Kondisi demikian menyebabkan pengelolaan airtanah di Pulau Pramuka mendesak untuk segera di lakukan, mengingat kerusakan airtanah akan sulit untuk dipulihkan kembali.

Kata Kunci: Airtanah, Distribusi Spasial, Klorida, Pulau Sangat Kecil

\section{A. PENDAhULUAN}

Indonesia merupakan negara kepulauan dengan jumlah pulau sekitar 17.508 (Tuwo, 2011). Kodoatie (2012) mengungkapkan bahwa dari 17.508 pulau di Indonesia, 5 pulau memiliki luas $>10.000 \mathrm{~km}^{2}, 26$ pulau memiliki luas antara $2.000-10.000 \mathrm{~km}^{2}$, dan sisanya sejumlah $17.477(99,8 \%)$ merupakan pulau dengan luas $<2.000 \mathrm{~km}^{2}$. Hal ini berarti bahwa sekitar 99,8\% pulau di Indonesia masuk dalam kategori pulau kecil, yaitu pulau dengan luas kurang dari $2.000 \mathrm{~km}^{2}$ dan atau memiliki lebar kurang dari $3 \mathrm{~km}$ (Falkland, 1991; 1992; 1993).

Pulau dengan luas kurang dari $100 \mathrm{~km}^{2}$ disebut sebagai pulau sangat kecil. Pulau ini memiliki ciri hidrologi yang unik yang menyebabkan pulau ini memiliki sumberdaya air yang sangat terbatas (Cahyadi, 2012). Pulau sangat kecil memiliki sumberdaya air yang terbatas karena memiliki luas wilayah tangkapan hujan yang sempit (Hehanusa dan Bakti, 2005). Faktor lain yang menyebabkan terjadinya keterbatasan sumberdaya air di pulau kecil adalah adanya interaksi antara air tawar dengan air laut yang membentuk lensa airtanah (Cahyadi, dkk. 2013). Lebih lanjut Cahyadi dkk (2013) menjelaskan bahwa lensa airtanah ini 
merupakan cadangan air tawar di pulau kecil yang besarnya sangat tergantung dengan material penyusun batuan, luas pulau, topografi pulau, curah hujan, serta kondisi perairan laut di sekitar pulau kecil (bathimetri, gelombang dan arus).

Falkland (1991) menyebutkan bahwa airtanah merupakan sumberdaya air yang paling potensial di pulau sangat kecil. Kondisi demikian disebabkan pada pulau sangat kecil tidak diketemukan sungai dan mataair yang bersifat perenial. Pemanfaatan curah hujan melalui penampung air hujan (PAH) menjadi salah satu alternatif yang banyak dilakukan di pulau sangat kecil. Namun demikian, pemanfaatan air hujan di lokasi kajian sudah tidak dilakukan lagi, sehingga airtanah menjadi satu-satunya sumberdaya air alami yang dimanfaatkan.

Penelitian ini bertujuan untuk mengetahui (1) sebaran spasial salinitas airtanah berdasarkan kandungan klorida di Pulau Pramuka, Provinsi DKI Jakarta. Kajian ini diharapkan dapat menjadi masukan dalam pengelolaan Pulau Pramuka yang sejak Tahun 2003 ditetapkan sebagai ibukota Kabupaten Kepulauan Seribu (Afadlal, dkk. 2011) pada khususnya, dan menjadi masukan dalam pengelolaan pulau sangat kecil di seluruh Indonesia pada umumnya.

\section{B. METODE PENELITIAN}

Pengambilan sampel dilakukan dengan metode sistematik random sampling sebanyak 10 sampel airtanah. Sampel dianalisis di laboratorium hidrologi dan kualitas air Fakultas Geografi UGM. Nilai kandungan klorida pada masing-masing sampel kemudian di analisis dengan menggunakan klasifikasi Stuyfzand dalam Purnama (2010) (Tabel 1) untuk menentukan kualitas air berdasarkan salinitasnya. Distribusi spasial dari nilai salinitas dianalisis dengan melakukan interpolasi nilai salinitas pada sampel yang diambil. Metode interpolasi yang digunakan adalah metode Kriging yang menurut Hadi (2005) memiliki kualitas yang baik dalam pemetaan sumberdaya airtanah.

Tabel 1. Klasifikasi Salinitas Metode Stuyfzand

\begin{tabular}{|l|l|l|l|}
\hline No & Tipe Utama & Kode & $\mathbf{C l}^{-}(\mathbf{m g} / \mathbf{l})$ \\
\hline 1 & Air Tawar & F & $<150$ \\
\hline 2 & Air tawar-payau & Fb & $150-300$ \\
\hline 3 & Air payau & B & $300-10^{3}$ \\
\hline 4 & Air payau-asin & Bs & $10^{3}-10^{4}$ \\
\hline 5 & Air asin & S & $10^{4}-2.10^{4}$ \\
\hline 6 & Air asin kadar tinggi & H & $2.10^{4}$ \\
\hline
\end{tabular}

Sumber: Purnama, 2010

\section{HASIL DAN PEMBAHASAN}

Kandungan klorida dalam kualitas air dapat digunakan untuk mengetahui tipe utama kimia air tersebut. Menurut Stuyfzand (1986) dalam Purnama (2010), tipe utama air tanah berdasarkan kandungan klorida $\left(\mathrm{Cl}^{-}\right)$dapat dibedakan menjadi 6, yaitu: air tawar, air tawarpayau, air payau, air payau-asin, air asin dan air asin kadar tinggi. Hasil analisis data lapangan menunjukkan bahwa kadar $\mathrm{Cl}^{-}$di Pulau Pramuka berkisar 500 ppm hingga 35.000 ppm. Hal ini disebabkan karena bentuk lahan dari Pulau Pramuka yang berupa rombakan 
koral dengan luas yang sangat sempit (16 Ha), sehingga masih dipengaruhi oleh aktivitas air laut.

Gambar 1 menunjukkan bahwa di tengah pulau cenderung memiliki kandungan klorida yang lebih rendah, yaitu sekitar 500 ppm hingga 5000 ppm. Kondisi ini disebabkan oleh pengaruh air laut yang semakin ke tengah semakin sedikt. Gambar ini menunjukkan bahwa terdapat dua wilayah yang terpisah yang memiliki kandungan klorida rendah. Hal ini menunjukkan adanya lensa airtanah pada akuifer di Pulau Pramuka.

Berdasarkan nilai kandungan klorida yang dipetakan, diketahui bahwa kualitas airtanah di Pulau Pramuka terdiri dari air tawar-payau,air payau, air payau-asin, air asin dan air asin kadar tinggi (Gambar 2). Hasil pemetaan menunjukkan bahwa telah terjadi intrusi air laut ke dalam airtanah di Pulau Pramuka dan memnyebabkan terbentuknya lensa airtanah pada akuifer pulau ini. Hal ini ditunjukkan pada kualitas air tipe air tawar-payau yang terpisah-pisah. Kondisi kualitas air di Pulau Pramuka dapat dikatakan buruk karena tidak ada kualitas air tipe air tawar. Hal ini kemungkinan disebabkan bentuklahan dari Pulau Pramuka yang berupa pulau Koral dan rendahnya curah hujan di pulau ini.

Hasil penelitian ini memiliki kesamaan penelitian sebelumnya yang dilakukan oleh Cahyadi, dkk. (2013) yang melakukan pemetaan salinitas berdasarkan nilai daya hantar listrik (DHL). Hasil penelitian sebelumnya juga menghasilkan kualitas air yang mirip, di mana kualitas air terbaik pada penelitian tersebut adalah kualitas agak payau (antara tawar dan payau). Penelitian tersebut juga menghasilkan sebaran spasial yang mirip dengan hasil penelitian ini.

Klasifikasi kualitas air dengan penciri kandungan klorida dalam airtanah cenderung lebih valid dibandingkan dengan menggunakan nilai DHL. Hal ini dikarenakan pada penggunaan nilai DHL cenderung terbatas pada nilai maksimum yang dapat diukur oleh alat (EC meter) yaitu sebesar $20.000 \mu \mathrm{mhos} / \mathrm{cm}$, sedangkan pada pengukuran kandungan klorida dapat mengukur sampai pada nilai yang tinggi. 


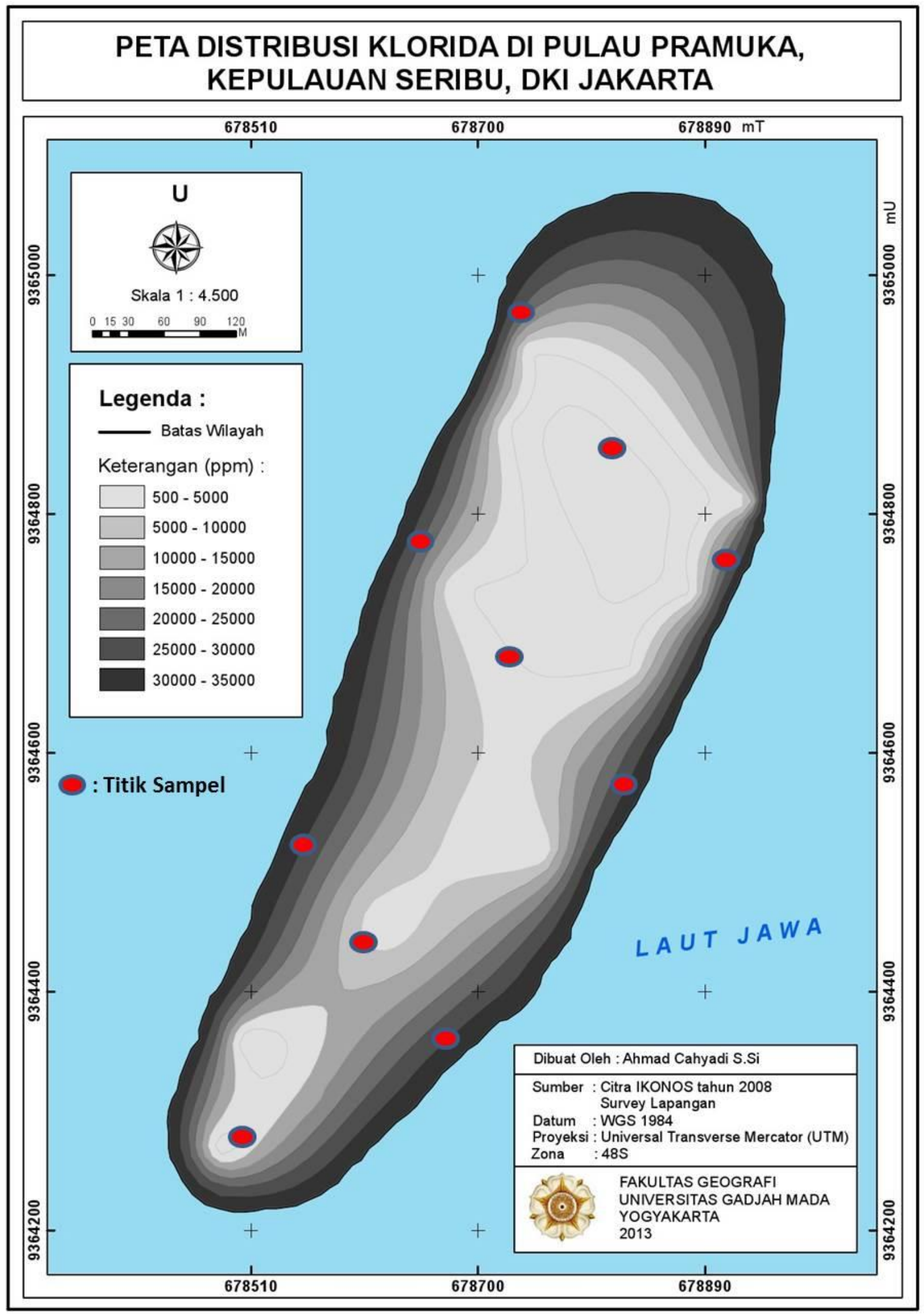

Gambar 1. Distribusi Spasial Kandungan Klorida Airtanah di Pulau Pramuka 


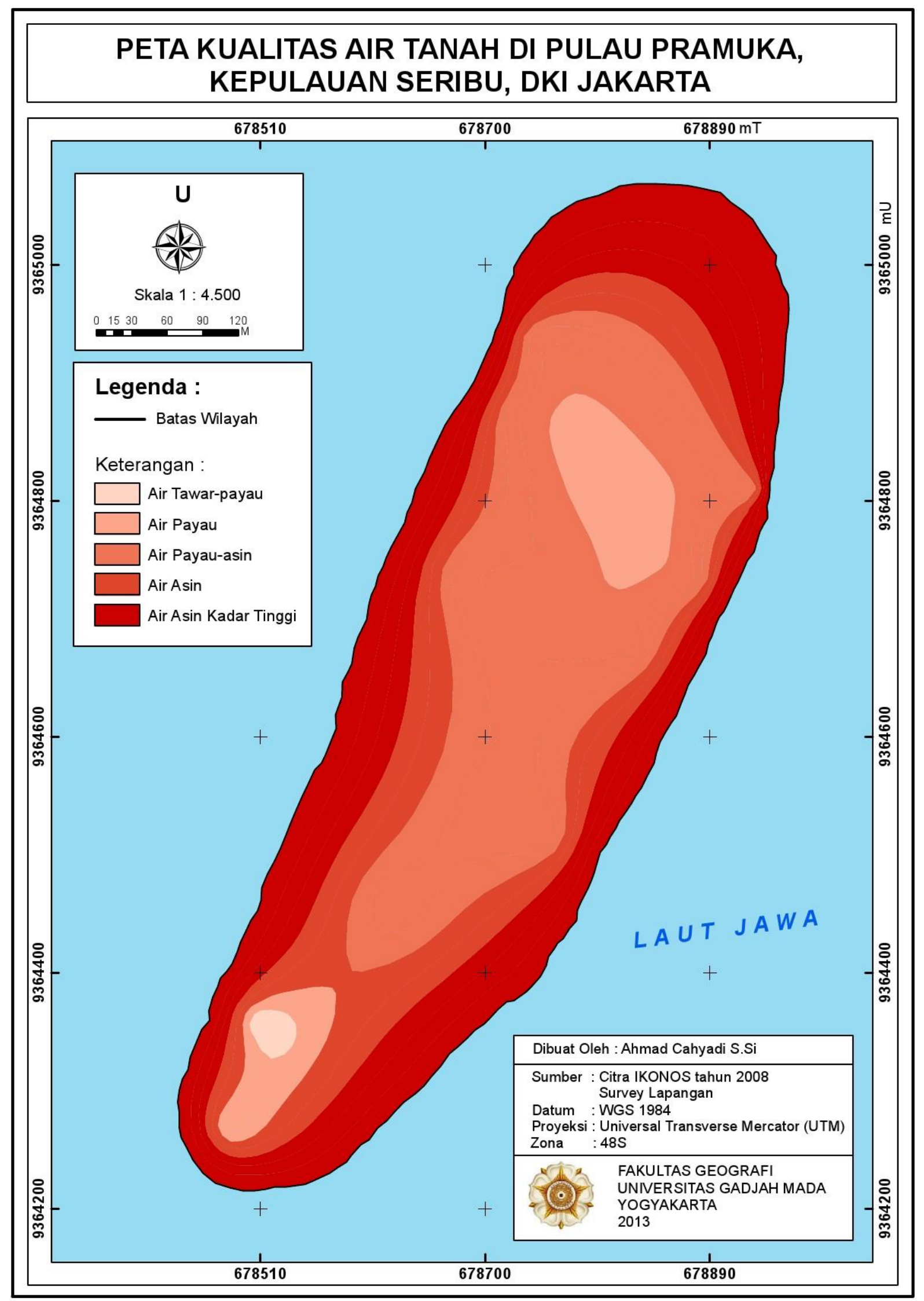

Gambar 2. Distribusi Spasial Kualitas Airtanah di Pulau Pramuka 


\section{PENUTUP}

Berdasarkan hasil penelitian yang telah dilakukan, maka diketahui bahwa kualitas airtanah di Pulau Pramuka terdiri dari air tawar-payau,air payau, air payau-asin, air asin dan air asin kadar tinggi. Hasil penelitian menunjukkan bahwa hasil penelitian sebelumnya yang melakukan pemetaan salinitas berdasarkan nilai daya hantar listrik memiliki kemiripan hasil. Namun demikian, metode analisis berdasarkan nilai kandungan klorida memiliki kelebihan karena tidak dibatasi oleh nilai maksimum yang dapat diukur oleh alat (EC meter). Alat tersebut hanya dapat mengukur nilai daya hantar listrik sampai dengan $20.000 \mu \mathrm{mhos} / \mathrm{cm}$, sedangkan pada pengukuran kandungan klorida dapat mengukur sampai pada nilai yang tinggi.

\section{E. PENGAKuAN}

Penelitian ini merupakan sebagian dari penelitian berjudul "Kajian Potensi Sumberdaya Air Pulau Sangat Kecil: Studi Kasus Pulau Koral Pramuka, Kabupaten Kepulauan Seribu, DKI Jakarta”. Penelitian ini didanai oleh Fakultas Geografi Universitas Gadjah Mada melalui Dana Penerimaan Negara Bukan Pajak, Fakultas Geografi Universitas Gadjah Mada Tahun Anggaran 2013.

\section{DAFTAR PUSTAKA}

Afadlal; Wijonarko, S.; Meifina; Septi, A.; Ongkosongo, A.E. dan Ongkosongo, O.S.R. 2011. Kondisi Lingkungan Sosial, Ekonomi dan Budaya di Pulau Pramuka, dalam Ongkosongo, O.S.R.; Wijonarko, S. Dan Afadlal. 2011. Rona Lingkungan Pulau Pramuka. Jakarta: Lembaga Ilmu Pengetahuan Indonesia (LIPI), Pusat Penelitian Oseanografi, Balai Dinamika Laut, Kolompok Penelitian Geologi Laut.

Cahyadi, A. 2012. Permasalahan Sumberdaya Air Pulau Kecil. Prosiding Seminar

Lingkungan Hidup 2012. Magister Ilmu Lingkungan, Universitas Diponegoro Semarang.

Cahyadi, A.; Marfai, M.A.; Tivianton, T.A.; Wulandari; Hidayat, W. 2013. Analisis Distribusi

Spasial Salinitas Airtanah di Pulau Pramuka, Kepulauan Seribu, DKI Jakarta. Makalah dalam Seminar Nasional Pendayagunaan Informasi Geospasial 2013. Fakultas Geografi, Universitas Muhammadiyah Surakarta, 20 Juni 2013.

Falkland, C. A. 1991. Hydrology and Water Resources of Small Island: A Practical Guide. Paris: UNESCO.

Falkland, C. A. 1992. Small Tropical Island: Water Resources of Paradises Lost. Paris: UNESCO.

Falkland, C. A. 1993. Hydrology and Water Management in Small Tropical Island. Proceeding of The Yokohama Symposium on Hydrology on Warm Humid Regions. July, 1993.

Hadi, I. 2005. Metode Kriging untuk Memetakan Konfigurasi Air Tawar Pulau Kecil. dalam Hehanusa, P.E. dan Bakti, H. 2005. Sumber Daya Air di Pulau Kecil. Bandung: Lembaga Ilmu Pengetahuan Indonesia, Pusat Penelitian Geoteknologi.

Hehanusa, P.E. dan Bakti, Hendra. 2005. Sumber Daya Air di Pulau Kecil. Bandung: LIPI Press.

Kodoatie, Robert J. 2012. Tata Ruang Air Tanah. Yogyakarta: Penerbit ANDI. 
Simposium Nasional Sains Geoinformasi

Fakultas Geografi Universitas Gadjah Mada Yogyakarta 2013

Purnama, S. 2010. Hidrologi Air Tanah. Yogyakarta: Penerbit Kanisius.

Suherman, D. 2007. Mata Air Sebagai Sumber Air Bersih di Pulau Kai-Kecil, maluku Tenggara. dalam Hehanusa, P.E. dan Bhakti, H. 2004, (eds). Sumber Daya Air di Pulau Kecil. Bandung: Lembaga Ilmu Pengetahuan Indonesia, Pusat Penelitian Geoteknologi. 